\title{
DETERMINANTS OF CHOICE OF CLIMATE CHANGE ADAPTATION STRATEGIES AMONG RURAL FARMING HOUSEHOLDS IN LOKOJA LOCAL GOVERNMENT AREA, KOGI STATE, NIGERIA
}

\author{
Haruna Ibrahim Opaluwa ${ }^{1 凶}$, Gbenga Opeyemi ${ }^{1}$, Momoh John Eleojo ${ }^{1}$ \\ ${ }^{1}$ Kogi State University Anyigba, Nigeria
}

\begin{abstract}
The study examined factors influencing the choice of climate change adaptation strategies among rural farming households in Lokoja Local Government Area, Kogi State, Nigeria. A total of 115 rural farmers constituted the sample size of this study. Descriptive and relevant inferential statistics such as the multivariate probit model were used. The perceived effects of climate change in the studied area included erosion/flooding, increase in rainfall, scarcity of resources, increase in temperature, and increase in pest and disease infestation. The major adaptation strategies adopted by the farmers in the studied area included change in planting date $(72.17 \%)$, change in harvesting date $(67.83 \%)$, construction of drainage around homes/farms $(67.83 \%)$, income diversification $(64.35 \%)$, and planting cover crops $(58.26 \%)$. The results concerning the factors influencing the choice of adaptation showed that gender, age, years of farming experience, access to credit, and training on climate change were the factors that influenced the choice of adaptation strategies in the studied area. Major constraints to adoption of adaptation strategies in the studied area were also identified. The study concluded that selected socio-economic characteristics influenced the choice of rural farmers` adaptation strategies utilised in the studied area. Government policies should be sensitive to support trainings on climate change, education, credit access, farm and household size.
\end{abstract}

Keywords: adaptation strategies, climate change, determinants, Nigeria

\section{INTRODUCTION}

Climate change is now a global phenomenon that portends significant developmental challenges. The agricultural sector is no exception to the impact of climate change (Choptiany et al., 2015). The potential and predicted impacts of climate change are resulting in increased frequency and intensity of rainfall, floods and droughts, rising temperature, storms and reduced rainfall variability which are mostly reflected in the form of reducing crop yield and threatening food security (Intergovernmental Panel on Climate Change (IPCC, 2015). Climate change affects agriculture through rainfall variability. A rain-fed agricultural production system is vulnerable to seasonal variability which affects the livelihood outcomes of farmers and landless labourers who depend on such system of agricultural production (IPCC, 2015). The agricultural sector is showing an increasingly high level of vulnerability and impact. Climate change across Africa is exacerbated by a low level of adaptation and mitigation (Montpellier Panel Report, 2015).

Consequently, climate change is perhaps the most serious environmental threat to the fight against hunger, malnutrition, diseases and poverty in Africa, mainly through its impact on agricultural productivity. The negative effect on agricultural yields will be exacerbated by

\footnotetext{
$\bowtie$ Opaluwa Haruna Ibrahim, Department of Agricultural Economics and Extension, Faculty of Agriculture, Kogi State University Anyigba, P.M.B. 1008, Anyigba, Kogi State, Nigeria, e-mail: opaluwa.hi@ksu.edu.ng, https://orcid.org/0000-0002-9161-9639
} 
more frequent extreme weather events (Fawole and Olajide, 2012). For example, IPCC (2015) stated that rising atmosphere of carbon dioxide concentration leads to a greater temperature change. Rural poor communities rely greatly for their survival on agriculture and livestock husbandry which are amongst the most climatesensitive economic sectors (Bidoli et al., 2012). While climate change is a global phenomenon, its negative impacts are more severely felt by poor people in developing countries who rely heavily on natural resources for their livelihoods. In view of this, there appears to be a great decline in crop production being stimulated by impacts of climatic variations on natural resource use among farmers in most parts of Nigeria.

Despite the importance of farming to Nigeria's rural economy, the production and yields are presently being threatened by climate change. Adaptation is one of the critical tools that can be used to fight the dangers associated with climate change. Adaptation involves adjustments in ecological, social, or economic systems in response to actual or expected climatic stimuli and their effects (Nnaemeka, 2015). A conclusion was arrived at by Nnaemeka (2015) that there is a great potential to increase food production under climate change in many regions of the world if adaptation is taken into consideration. According to the report, adaptation has the potential to reduce food deficits in Africa from $50 \%$ to $20 \%$.

Adaptation to climate change involves any activity that reduces the negative impacts of climate change and/or takes advantage of new opportunities that may be presented (Wang et al., 2009; Agrawal, 2009). Adaptation to climate change is a two-step process; the first step requires farmers to perceive a change in climate and the second step requires them to act through adaptation (Deressa et al., 2011). Despite their vulnerability to climate change, these rural producers have over the years developed and implemented extensive indigenous best practices and adaptive strategies to cope with climate-related challenges. However, the choice of adaptation strategies adopted by individual farmers varies and different factors could be responsible for the different choice of adaptation strategies.

In order to be able to effectively manage climate change, there is a need for knowledge of the noticeable effects of climatic change as observed by rural community first. The ability of a farmer to discover a visible change in the climate will enable him/her to decide on the adaptation strategies needed to adapt to the change.
The adaptation methods used by farmers contribute a lot to the farmers' output. There is a need to know several factors influencing the farmers' decision as well as choice of adaptation strategies. The study was carried in rural farming communities in Lokoja Local Government Area, Kogi State, Nigeria with the view to identify the different adaptation strategies utilised in the studied area and the factors influencing the choice of adaptation strategies adopted by individual farmers. The significance of this study is in its potential to contribute to climate adaptation studies and helping to enrich the wealth of literature on factors influencing the choice of adaptation strategies, especially among rural farming households. The main objective of this study is to determine factors influencing the choice of climate change adaptation strategies in Lokoja Local Government Area, Kogi State, Nigeria. The specific objectives of the study include:

- describing the socioeconomic characteristics of rural households in Lokoja Local Government Area, Kogi State, Nigeria;

- identifying the observable effects of climate change in the studied area;

- identifying the adaptation strategies utilised by rural households in the studied area;

- estimating the factors influencing the choice of climate change adaptation strategies in the studied area; and

- investigating the constraints on the adoption of climate change adaptation strategies in the studied area.

\section{METHODOLOGY}

\section{The study area}

The studied area is Lokoja in Kogi State of Nigeria. The Lokoja local government is a medium-sized urban centre in central Nigeria. The study was carried out in the rural part of the local government where farming is the main occupation of residents. Lokoja is a confluence town and is contiguous to a lot of water bodies and wetland areas. It is the capital of Kogi State, Nigeria. It is located between latitude $7^{\circ} 49^{\prime} \mathrm{N}$ and longitude $6^{\circ} 45^{\prime} \mathrm{E}$. It has an estimated landmass of $63.82 \mathrm{sq} . \mathrm{km}$. It shares boundaries with Niger, Kwara, Nassarawa and the Federal Capital territory to the north. To the east, it is bounded by Benue State, to the south by Adavi and Okehi L.G.As respectively and to the west by Kabba L.G.A. The annual rainfall is between $1016 \mathrm{~mm}$ and $1524 \mathrm{~mm}$ 
with its mean annual temperature never below $27^{\circ} \mathrm{C}$. The rainy season lasts from April to October. The dry season, which lasts from November to March, is very dusty and cold as a result of the north easterly winds, which bring in the Harmattan (Ogunjumo et al., 2000). In general, the topographic relief is undulating and characterised by high hills. Lokoja has a population of about 77,516 in 1991 which has increased to 195,261 in 2006, with 100,573 males and 94,688 females (National Population Commission, 2006). The residents of the rural part which is comprised of villages in the fringes of the major town indicate farming as their main occupation.

\section{Sampling procedure}

This study made use of multi-stage random sampling. The use of this procedure was informed by the fact that, the multi-stage random sampling procedure allows for an effective and fairly even representation of all the units within the studied area. The sampling procedure was carried out in stages, and the peculiar characteristics were taken into consideration at all the sampling stages to ensure equal representation. In stage one, two wards from the local government area were randomly chosen. In the second stage, two villages in each of the wards were chosen randomly giving a total of four villages. In stage three, thirty farming households in each of the four villages were randomly selected. This gave a total of 120 sampled respondents. However, only 115 completed questionnaires were returned.

\section{Method of data collection}

In carrying out this study, primary data were used. The data were elicited using a structured questionnaire, which was administered to rural farmers in the studied area.

\section{Method of data analysis}

Descriptive and inferential statistics were used in this research. The Likert scale and multivariate probit model were further used to analyse the data.

\section{Multivariate discrete choice model}

The multivariate probit model was employed to investigate the factors that determine the choice of adaptation strategies. Farmers' adaptation activities in response to climate change can be influenced by various factors; however, the model was considered suitable because multivariate probit (MVP) models allow the use of several chain of bivariate probit estimators. This study includes analyses of various factors that influence the choice of farmers concerning adaptation methods. Farmers can carry out many adaptation actions as long as the strategy provides them with a certain number of benefits. Unlike in the ordinary least square method (OLS), the multivariate model ensures statistical efficiency in the estimations of available choices as shown below (Lin et al., 2005). Finally, five most adopted adaptation strategies were used as the dependent variables.

\section{Model specification}

The study assumed that each subject has a covariate vector that can be any mixture of discrete and continuous variables. Each subject produces J distinct quantal responses or is classified with respect to $\mathrm{J}$ dichotomous categories. Specifically, let $u_{j}=\left(u_{i} l \ldots, u_{t}\right)$ denote the collection of observed dichotomous $0 / 1$ responses in $\mathrm{J}$ variables on the $i$ th subject, $i=1 \ldots n, x_{i j}$ be a $k_{i} \times 1$ vector of covariates, $=k_{1}+\ldots+k_{j}$, and

$$
X_{i}=\left[\begin{array}{cccc}
x j i & 0 & \ldots & 0 \\
0 & x i 2 & \ldots & 0 \\
0 & 0 & \ldots & x i j
\end{array}\right]
$$

be a $J \times k$ matrix. The following MP model was formulated

Let $z_{i}=\left(z_{i} l \ldots z_{\jmath} J\right) 0$ denote a J-variate normal vector of "response strengths" so that

$$
z_{i}=X_{i} B+\varepsilon_{i} i=1 \ldots . n
$$

where:

$B^{\prime}=\left(b_{1 \ldots b j}^{\prime}, b_{j}-\right.$ is a $k_{j} \times 1$ unknown parameter vector $\varepsilon_{i}-$ is a $\mathbf{J} \times 1$ vector of residuals that is distributed as $\mathrm{N}[0, \Sigma]$, and

$$
u_{i j}=\left\{\begin{array}{l}
1 \text { xij }>0 \\
0 \text { otherwise }
\end{array}\right.
$$

$$
\begin{aligned}
& j=1 \ldots \mathrm{J} \\
& Y_{1}=1 \text { if } X^{i} B+E>0 \\
& Y_{1}=0 \text { if } X+\mathrm{E}<0 i=1,2,3, \ldots n
\end{aligned}
$$
where:

$Y_{i}$ - is a vector of dependent variables (each serves as adaptation choice)

$X^{\prime}-$ is a vector of explanatory variables

$\beta i-$ is a vector of coefficients

$\varepsilon_{i}$ - is a random error term and $\mathrm{n}$ is a number of observations with zero means and a unitary variance. 
Opaluwa, H. I., Opeyemi, G., Eleojo, M. J. (2020). Determinants of Choice of Climate Change Adaptation Strategies among Rural Farming Households in Lokoja Local Government Area, Kogi State, Nigeria. J. Agribus. Rural Dev., 3(57), 299-308. http://dx.doi. org/10.17306/J.JARD.2020.01324

\section{Measurement of variables}

For the purpose of this study, the five major adaptation strategies adopted by the farmers were used as the dependent variable for the empirical estimation;

$X_{1}=$ Age of the household head (measured in years),

$X_{2}=$ Gender of the household head (Dummy: $1=$ Male, $0=$ if otherwise),

$X_{3}=$ Farming experiencing of household head (measured by years of farming)

$X_{4}=$ Education level (number of years of schooling of the household head),

$X_{5}=$ Household size (numbers of people in each household)

$X_{6}=$ Farm size (measure in hectares)

$X_{7}=$ Membership of social organisation (Dummy: 1

$=$ Yes, $0=$ if otherwise),

$X_{8}=$ Access to credit facilities $(1=$ for access to formal credit, 0 if otherwise),

$X_{9}=$ Access to climate information $(1=$ for access to climate information, 0 if otherwise),

$X_{10}=$ Previous training on climate $(1=$ household head had any training on climate change, 0 if otherwise).

\section{RESULTS AND DISCUSSIONS}

Table 1 indicates that many $(34.8 \%)$ of the farming households' inhabitants were within the age range of 40 and 49 years, $(31.3 \%)$ were within the age bracket of 20 and 29 years, $(17.4 \%)$ were in the age range of 30 and 39 . And $(5.2 \%)$ of the farming households had inhabitants who were over 60 . The result showed that the average age of the respondents was 37.7 years. This implies that the majority of respondents were young and still active economically. This is expected to have a positive implication for farming. According to Sofoluwe et al. (2011), young farmers have been found to be more knowledgeable about better practices and may be more willing to bear a risk and adopt better farming techniques. The majority of $(70.43 \%)$ of respondents in the studied area were males. The study shows that more men were involved in farming than women in the sample. This implies that farming households in the studied area are dominated by males. This has implications for gender equality and calls for mainstreaming of women, especially in agriculture where they constitute a bulk of the workforce. The male dominance has been often attributed to the laborious nature of peasant farming due to a high dependence on manual labour (Coster and Adeoti, 2015).
Table 1. Socioeconomic characteristics of households

\begin{tabular}{lccc}
\hline $\begin{array}{c}\text { Socioeconomic } \\
\text { characteristics }\end{array}$ & Frequency & Percentage & $\begin{array}{c}\text { Mean/ } \\
\text { mode }\end{array}$ \\
\hline \multicolumn{1}{c}{1} & 2 & 3 & 4 \\
\hline Age (years) & 36 & 31.3 & \\
$20-29$ & 20 & 17.4 & \\
$30-39$ & 40 & 34.8 & 37.7 \\
$40-49$ & 13 & 11.3 & \\
$50-59$ & 6 & 5.2 & \\
Above 60 & & & \\
Gender & 81 & 70.4 & \\
Male & 34 & 29.6 & \\
Female & &
\end{tabular}

Years of farming

experience

$\begin{array}{lrr}1-10 & 41 & 35.7 \\ 11-20 & 45 & 39.2 \\ 21-30 & 19 & 16.5 \\ 31-40 & 8 & 6.9 \\ \text { Above } 40 & 2 & 1.7\end{array}$

Marital status

$\begin{array}{lrr}\text { Single } & 34 & 29.6 \\ \text { Married } & 73 & 63.5 \\ \text { Divorced } & 1 & 0.9 \\ \text { Widowed } & 7 & 6.0\end{array}$

Education level

$\begin{array}{llr}\text { No formal education } & 10 & 8.7 \\ \text { Primary education } & 16 & 13.9 \\ \text { Secondary education } & 48 & 41.7 \\ \text { Tertiary education } & 41 & 35.7\end{array}$

Household size

$\begin{array}{lll}1-5 & 78 & 67.8 \\ 6-10 & 28 & 24.4\end{array}$

Above 10

9

7.8

Primary occupation

\begin{tabular}{lll} 
Farming & 53 & 46.1 \\
Trading & 25 & 21.7 \\
\hline
\end{tabular}


Opaluwa, H. I., Opeyemi, G., Eleojo, M. J. (2020). Determinants of Choice of Climate Change Adaptation Strategies among Rural Farming Households in Lokoja Local Government Area, Kogi State, Nigeria. J. Agribus. Rural Dev., 3(57), 299-308. http://dx.doi. org/10.17306/J.JARD.2020.01324

Table 1 cont.

\begin{tabular}{|c|c|c|c|}
\hline 1 & 2 & 3 & 4 \\
\hline Civil/public servant & 19 & 16.5 & \\
\hline Artisanry & 3 & 2.6 & \\
\hline Other & 15 & 13.1 & \\
\hline \multicolumn{4}{|l|}{ Farm size(hectares) } \\
\hline $1-4$ & 93 & 80.9 & \multirow{3}{*}{3.2} \\
\hline $5-9$ & 18 & 15.6 & \\
\hline Above 10 & 4 & 3.5 & \\
\hline \multicolumn{4}{|l|}{ Annual income } \\
\hline Less than NGN 100,000 & 29 & 25.2 & \multirow{5}{*}{$\begin{array}{c}\text { NGN } \\
367,765.1\end{array}$} \\
\hline NGN $100,000-400,000$ & 53 & 46.9 & \\
\hline NGN 400,001-800,000 & 24 & 20.9 & \\
\hline NGN $800,001-1200,000$ & 3 & 2.6 & \\
\hline Above NGN-1200,000 & 5 & 4.4 & \\
\hline \multicolumn{4}{|l|}{$\begin{array}{l}\text { Member of social } \\
\text { organisation }\end{array}$} \\
\hline Yes & 51 & 47.0 & \\
\hline No & 61 & 53.0 & \\
\hline \multicolumn{4}{|l|}{ Access to credit } \\
\hline Yes & 47 & 40.9 & \\
\hline No & 68 & 59.1 & \\
\hline
\end{tabular}

Source: computed from field data, 2018.

A greater proportion (39.2\%) of households had between 11 and 20 years of farming experience. The average of farming experience was 17.6 years. This implies that a great number of respondents have been practicing agriculture long enough to be able to notice significant changes in the climate as they affect their farming activities. According to Maddison (2006), and Nhemachena and Hassan (2007) experience in farming increases the probability of uptake of adaptation measures to climate change. The majority $(63.5 \%)$ of farmers were married with about $29.57 \%$ being single. Okoro (2012) and Egbule (2010) also revealed in their separate studies that the majority of farmers in Nigeria are married. This shows that married people dominate agricultural production in the studied area. This implies an increase in the number of mouths to feed as well as the number of family-farm labour availability.
A greater proportion $(41.7 \%)$ of farmers indicated a secondary school certificate as their highest qualification, $8.7 \%$ had no formal education, $13.91 \%$ had primary education, and $35.65 \%$ tertiary education. This finding shows that the farmers possessed some form of literacy. The level of education acquired had an implication in the utilisation or adoption of information on agriculture. Idrisa et al. (2012) reported that education plays an important role in creating awareness in farming communities because educated people are better equipped to source information. With regards to climate change information, Deressa et al. (2008) revealed that formal education increases climate change awareness and the likelihood of adaptation.

The result further shows that most $(67.83 \%)$ household size was between 1 and 5 persons, $(24.4 \%)$ between 6 to 10 persons while the remaining $7.83 \%$ above 11 persons. The average number of persons per household was 5.3 persons which is about the national average of 5 persons in rural Nigeria (NBS, 2009). This average number of household size could be an advantage for use as family farm labour on adaptation strategies. This is consistent with the finding of Keil (2001) that the household size influences the decision of farmers to undertake the adaptation measures given that the household labour is the whole supplier of the required labour for undertaking the farming and adaptation practices. The result shows that many of the rural residents $(46.1 \%)$ are engaged in farming, $21.7 \%$ are traders, $16.5 \%$ are civil servants, $2.6 \%$ are artisans and other $13.0 \%$ have other occupation.

On an estimated annual income, many (46.9\%) of the farmers reported that their estimated annual income was between NGN 100, 000.00-400, 000.00, 25.2\% reported earning less than NGN 100,000, 20.9\% stated that their estimated annual income was between NGN N 400,001.00-800,000.00, Only 4.4\% reported an estimated annual income above NGN 1,200,000.00. The average annual income was NGN 367,765.2. The average estimated annual income could be said to be low and this could be a constraint on an effective adaptation to climate change. The result shows that many $(53.0 \%)$ of the farmers in the studied area do not belong to any social organisation, while $47.0 \%$ belong to a social organisation. The result shows that about $59.1 \%$ of the farmers do not have access to credit while $40.9 \%$ of the farmers in the studied area had access to credit. Access to credit is necessary for an effective adaptation; this is because 
Opaluwa, H. I., Opeyemi, G., Eleojo, M. J. (2020). Determinants of Choice of Climate Change Adaptation Strategies among Rural Farming Households in Lokoja Local Government Area, Kogi State, Nigeria. J. Agribus. Rural Dev., 3(57), 299-308. http://dx.doi. org/10.17306/J.JARD.2020.01324

Table 2. Perceived effects of climate change in the studied area

\begin{tabular}{clccccccc}
\hline \multirow{2}{*}{ S/NO } & \multicolumn{1}{c}{ Effects } & High & Moderate & Low & No & Total & Mean & Rank \\
\hline 1 & & 4 & 3 & 2 & 1 & & & \\
2 & Erosion/flooding & 84 & 15 & 6 & 3 & 396 & 3.44 & $1^{\text {st }}$ \\
2 & Increase in rainfall & 63 & 38 & 9 & 5 & 289 & 3.38 & $2^{\text {nd }}$ \\
3 & Scarcity of resources (food and water) & 53 & 41 & 16 & 5 & 372 & 3.24 & $3^{\text {rd }}$ \\
4 & Increase in temperature & 46 & 47 & 28 & 8 & 361 & 3.14 & $4^{\text {th }}$ \\
5 & Increase in pest and disease infestation & 29 & 50 & 27 & 9 & 329 & 2.86 & $5^{\text {th }}$ \\
6 & Poor yield of crops & 59 & 40 & 10 & 6 & 282 & 2.45 & $6^{\text {th }}$ \\
7 & Sudden change in weather condition & 24 & 27 & 41 & 23 & 282 & 2.45 & $6^{\text {th }}$ \\
8 & Death of animals & 8 & 47 & 41 & 19 & 274 & 2.38 & $8^{\text {th }}$ \\
9 & Decrease in rainfall & 20 & 21 & 50 & 28 & 271 & 2.36 & $9^{\text {th }}$ \\
10 & Migration of fish into deep waters & 15 & 18 & 26 & 56 & 222 & 1.93 & $10^{\text {th }}$ \\
\hline
\end{tabular}

Source: computed from field data, 2018.

Hint: Variables with 2.5 points and above were considered as a significant effect of climate change, while below 2.5 were considered as not significant. The cut-off point was estimated with a four-point Likert scale.

limited or no access to credit could be a limitation to adapting to climate change, as such adaptation comes at a cost. According to Nhemechena and Hassan (2007), access to credit, as well as access to extension services and awareness of climate change are some important determinants of the farm-level adaptation.

\section{Perceived Effects of Climate Change}

The major effects of climate change perceived by households in the studied area included erosion/flooding $(\mathrm{M}=3.44)$, increase in rainfall $(\mathrm{M}=3.38)$, scarcity of resources $(\mathrm{M}=3.24)$, increase in temperature $(\mathrm{M}=3.14)$ and increase in disease and pest infestation $(\mathrm{M}=2.86)$ which is as a result of increase in rain. The increase in rainfall was one of the most observed effects of climate change by the respondents.

\section{Adaptation strategies}

Households reported that they have used more than one type of adaptation strategies. This is in agreement with Coster and Adeoti (2015) who claim that a single adaptation strategy is not adequate in adapting to the impact of climate change given that a combination of several strategies is likely to be more effective than a single strategy.

From the result, the adaptation strategies adopted by the farmers in the studied area most often included
Table 3. Adaptation strategies employed by households

\begin{tabular}{lcc}
\hline \multicolumn{1}{c}{ Adaptation strategies } & Frequency & Percentage \\
\hline Planting cover crops & 84 & 68.26 \\
Change in planting date & 89 & 72.17 \\
Change in harvesting date & 85 & 68.83 \\
Planting drought resistant varieties & 41 & 26.98 \\
of crop & & \\
Switching from crop to livestock & 41 & 33.04 \\
Use of minimum tillage system & 42 & 33.04 \\
Use of irrigation system & 47 & 44.35 \\
Reforestation/Afforestation & 44 & 30.30 \\
Mixed farming practice & 46 & 49.50 \\
Migration & 61 & 53.04 \\
Religious beliefs and prayer & 71 & 61.74 \\
Construction of drainage around & 78 & 67.83 \\
homes/farms & & 64.35 \\
Income diversification & 75 & \\
\hline
\end{tabular}

*Note: multiple answers were allowed.

Source: field survey, 2018. 
Opaluwa, H. I., Opeyemi, G., Eleojo, M. J. (2020). Determinants of Choice of Climate Change Adaptation Strategies among Rural Farming Households in Lokoja Local Government Area, Kogi State, Nigeria. J. Agribus. Rural Dev., 3(57), 299-308. http://dx.doi. org/10.17306/J.JARD.2020.01324

Table 4. Factors influencing the choice of climate change adaptation (multivariate probit)

\begin{tabular}{|c|c|c|c|c|c|c|c|c|c|c|}
\hline \multirow[t]{2}{*}{ Variables } & \multicolumn{2}{|c|}{ Planting cover crop } & \multicolumn{2}{|c|}{$\begin{array}{c}\text { Change in planting } \\
\text { date }\end{array}$} & \multicolumn{2}{|c|}{$\begin{array}{c}\text { Change in harvest- } \\
\text { ing date }\end{array}$} & \multicolumn{2}{|c|}{$\begin{array}{l}\text { Construction of } \\
\text { drainage }\end{array}$} & \multicolumn{2}{|c|}{$\begin{array}{c}\text { Income } \\
\text { diversification }\end{array}$} \\
\hline & coef. & std. err & coef. & std. err & coef. & std. err & coef. & std. err & coef. & std err. \\
\hline Age & 0.008 & 0.006 & 0.003 & 0.005 & $0.011^{* *}$ & 0.005 & 0.004 & 0.005 & $-0.008^{*}$ & 0.005 \\
\hline Gender & $-0.933^{\prime}$ & 0.132 & 0.310 & 0.097 & $-0.016^{*}$ & 0.095 & $0.236^{* *}$ & 0.098 & 0.069 & 0.100 \\
\hline Farming experience & $-0.052^{*}$ & 0.032 & $0.001^{* *}$ & 0.002 & 0.001 & 0.002 & -0.003 & 0.002 & 0.003 & 0.002 \\
\hline Education level & -0.068 & 0.077 & -0.027 & 0.569 & $-0.135^{* *}$ & 0.055 & -0.035 & 0.057 & -0.017 & 0.058 \\
\hline Households size & -0.007 & 0.023 & -0.015 & 0.017 & -0.021 & 0.016 & $-0.027^{*}$ & 0.017 & 0.016 & 0.017 \\
\hline Farm size & -0.012 & 0.031 & 0.057 & 0.023 & 0.023 & 0.022 & $0.053^{* *}$ & 0.023 & -0.026 & 0.023 \\
\hline Social organisation & 0.047 & 0.124 & -0.022 & 0.091 & 0.047 & 0.089 & -0.010 & 0.092 & 0.063 & 0.094 \\
\hline Access to credit & 0.029 & 0.128 & 0.071 & 0.094 & 0.142 & 0.091 & 0.024 & 0.094 & $0.206^{* *}$ & 0.096 \\
\hline Access to information & 0.139 & 0.151 & -0.064 & 0.112 & 0.016 & 0.109 & 0.109 & 0.112 & 0.171 & 0.115 \\
\hline Training on climate & 0.013 & 0.128 & $0.329^{* * *}$ & 0.094 & $0.178^{*}$ & 0.092 & 0.094 & 0.095 & 0.117 & 0.097 \\
\hline Constant & 0.687 & 0.412 & 0.473 & 0.303 & 0.831 & 0.295 & 0.237 & 0.305 & 0.564 & 0.311 \\
\hline
\end{tabular}

$*, * *, * * *$ Represents $10 \%, 5 \%$ and $1 \%$ respectively.

Source: field survey, 2018.

change in planting date $(72.17 \%)$, change in harvesting date $68.83 \%$, construction of drainage around homes/ farms $(67.83 \%)$, income diversification $(64.35 \%)$, religious belief and prayer (61.74\%) and planting cover crops $(68.26 \%)$. This finding is in line with Ugwoke, Nnadi, Anaeto, Aja and Nwakwasi (2012) who reported that farmers practice adjustment of planting dates in order to adapt to the changing climate effects on crops. It is evident from the findings above that adapting to early rainfall will bring about change of planting date as both practices go in tandem. Also, closely related to this is the subsequent change in harvesting date; early planting has the tendency to lead to early harvesting. That is to say, a change in planting (whether early or late) will definitely result in changes to harvesting date. Planting of cover crops/mulching was another strategy used in adapting to climate change impacts. Other adaptation strategies applied by farming households in the area included migration (53.04\%), mixed-farming practice $(49.50 \%)$, use of irrigation system $(44.35 \%)$, use of minimum tillage system (33.04\%), switching from crop to livestock (33.04\%), reforestation/afforestation $(30.30 \%)$ and planting drought resistant varieties of crops $(26.96 \%)$.
For the purpose of this study, Table 3 summarises the adaptation strategies employed by the farmers. Out of 13 adaptation strategies identified by the farmers, the five main identified adaptation strategies were used for empirical estimation. The findings from the multivariate probit model showed that years of farming experience influenced the decision to adopt planting of cover crops as an adaptation strategy. The variable had a negative coefficient and was statistically significant at $10 \%$ level. This implies that the probability of adopting the adaptation strategy decreases as farmers grow in age (older). It suggests that aged farmers have less interest in taking up planting of cover crops as an adaptation strategy. Training on climate change influenced the decision to adopt a change in planting date as an adaptation strategy. The variable had a positive coefficient and was significant at $1 \%$ level. This implies that the more trained farmers were on climate change the more the chances of adopting a change in planting date as an adaptation strategy. In other words, farmers are more likely to use the change in planting date as an adaptation strategy if they had more training on climate change.

A household's choice to change planting date as a climate change adaptation strategy is found to be 
determined by years of farming experience. From the result, a positive relationship exists between the years of farming experience and the change in planting date. It was significant at $5 \%$ level. Due to the years spent in farming, households have noticed the trend of rainfall which makes them shift the planting date accordingly. The age of household head had a positive coefficient and was significant (at 5\% level) in terms of the choice of change in harvesting date as an adaptation strategy. This implies that for every additional year in age of the household head, the higher the probability of using the change in harvesting date as an adaptation strategy. The choice to change harvesting date as an adaptation strategy is influenced by gender, as gender had a negative relationship and was statistically significant at $10 \%$ level. The negative coefficient for gender shows that femaleheaded households are more likely to take up the change in harvesting date as an adaptation option.

From this research, it was shown that the education level or qualification influenced farmers' choice of changing the harvesting date as an adaptation strategy. The variable a had negative coefficient and was statistically significant at $5 \%$ level. The negative influence of education level on the adaption of change in harvesting date as an adaptation strategy implies that the adoption of this adaptation strategy increases with the decrease in farmers' level of acquired education. Evidence from various sources indicates that there is a positive relationship between the education level of households and the adaptation to climate changes (Maddison, 2006). Training on climate change influences the decision to adopt the change in harvesting date as an adaptation strategy. Training on climate change had a positive coefficient and was significant at $10 \%$ level. This implies that the more trained farmers were on climate change the more likely they were to adopt the change in harvesting date as an adaptation strategy. In other words, farmers will apply the change in harvesting date as an adaptation strategy most likely because they had training on climate change.

The choice of construction of drainage as an adaptation strategy was influenced by gender and farm size. Both variables had a positive relationship and were statistically significant at $5 \%$ level. This is consistent with the findings of earlier studies in Ethiopia that report a positive and significant effect of farm size on the decision to use water conservation measures (Amsalu and de Graaff, 2007; Kassa et al. 2013). This suggests that farmers who hold large farms are more likely to invest in conservation. The result suggests that the choice or decision to adopt construction of drainage as an adaptation strategy increase with male headed households and increase in farm size. The result also shows that the household size had a negative association with the construction of drainage as an adaptation strategy. The household size had a negative relationship and was statistically significant at $10 \%$ level. The respondents' decision to adopt diversification of income as an adaptation strategy was influenced by age of the household head and access to credit. The age of the household head had a negative relationship and was statistically significant at $10 \%$ level, while the household head's access to credit had a positive relationship and was statistically significant at 5\% level.

\section{Constraints on climate change adaptation}

The major constraints on climate change adaptation by farmers included high cost of farm labour $(\mathrm{M}=3.37)$, lack of finance to purchase or use some adaptation method ( $\mathrm{M}=3.25)$, poor government attention to the climate change problem $(\mathrm{M}=3.22)$, scarcity of farm input $(M=3.17)$, high cost of improved crop varieties $(M=3.12)$, limited income of households $(M=3.10)$, and high cost of farm inputs $(\mathrm{M}=3.09)$. Other constraints included poor storage facilities for harvested crops $(\mathrm{M}=$ 3.05), lack of access to improved crop varieties (2.96), and lack of information on climate change (2.94). Other constraints included, limited technology on climate change $(\mathrm{M}=2.78)$, no/limited subsidies on farm inputs $(\mathrm{M}=2.76)$ and low awareness of climate change adaptation methods $(\mathrm{M}=2.67)$.

These findings are in line with the work by Umunakwe (2011) who reported that constraints such as limited access to improved crop varieties and high cost of farm input, among others, prevent farmers from effectively adapting to the changing climate scenario. Adger et al. (2007) noted that the adaptation to climate change at individual, local and community level can be constrained by the lack of adequate resources. Similarly, this is in agreement with Hassan and Nhemachena (2008) who claim that availability of credit facilities to farmers will make it easy for farmers to adapt to climate change. Smit and Skinner (2002) reported that farmers often cite the lack of adequate financial resources as a major factor that constraints their use of adaptation measures which entails significant investments. It is well known that presently the world is making efforts to ensure that measures of adapting to and mitigating the dangerous 
Opaluwa, H. I., Opeyemi, G., Eleojo, M. J. (2020). Determinants of Choice of Climate Change Adaptation Strategies among Rural Farming Households in Lokoja Local Government Area, Kogi State, Nigeria. J. Agribus. Rural Dev., 3(57), 299-308. http://dx.doi. org/10.17306/J.JARD.2020.01324

Table 5. Constraints on climate change adaptation

\begin{tabular}{|c|c|c|c|c|c|c|}
\hline Constraint & $\begin{array}{l}\text { Very large } \\
\text { extent } 4\end{array}$ & $\begin{array}{l}\text { Large extent } \\
\quad 3\end{array}$ & $\begin{array}{c}\text { Little } \\
\text { extent } 2\end{array}$ & No extent 1 & Mean & Rank \\
\hline High cost of farm labour & 46.96 & 34.78 & 13.04 & 5.22 & 3.37 & $1^{\text {st }}$ \\
\hline $\begin{array}{l}\text { Lack of finance to purchase or use some of the adaptation } \\
\text { methods }\end{array}$ & 47.83 & 35.65 & 10.43 & 6.09 & 3.25 & $2^{\text {nd }}$ \\
\hline Poor government attention to the climate change problem & 53.91 & 25.22 & 9.57 & 11.31 & 3.22 & $3^{\text {rd }}$ \\
\hline Scarcity of farm input & 34.78 & 40.87 & 15.65 & 16.48 & 3.17 & $4^{\text {th }}$ \\
\hline High cost of improved varieties & 40.00 & 43.48 & 12.18 & 4.35 & 3.12 & $5^{\text {th }}$ \\
\hline High cost of improved varieties & 40.00 & 43.48 & 12.18 & 4.35 & 3.12 & $5^{\text {th }}$ \\
\hline Limited income of households & 44.35 & 31.30 & 13.91 & 10.44 & 3.10 & $6^{\text {th }}$ \\
\hline High cost of farm inputs & 38.26 & 40.87 & 12.17 & 8.7 & 3.09 & $7^{\text {th }}$ \\
\hline Poor storage facilities & 41.74 & 30.43 & 17.39 & 10.44 & 3.05 & $8^{\text {th }}$ \\
\hline Lack of access to improve crop varieties & 34.21 & 35.09 & 25.44 & 5.26 & 2.96 & $9^{\text {th }}$ \\
\hline Lack of information on climate change & 37.39 & 34.78 & 12.17 & 15.66 & 2.97 & $10^{\text {th }}$ \\
\hline Limited technology on climate change & 30.09 & 38.94 & 15.04 & 14.98 & 2.78 & $11^{\text {th }}$ \\
\hline No/limited subsidies on farm inputs & 28.70 & 35.65 & 18.26 & 17.39 & 2.76 & $12^{\text {th }}$ \\
\hline Irregularity of extension workers & 24.35 & 35.65 & 26.96 & 26.96 & 2.71 & $13^{\text {th }}$ \\
\hline Lack of information on weather forecast & 34.78 & 23.48 & 16.52 & 25.22 & 2.68 & $14^{\text {th }}$ \\
\hline Low awareness of climate change adaptation methods & 25.44 & 34.21 & 24.56 & 15.70 & 2.67 & $15^{\text {th }}$ \\
\hline Limited knowledge on water management method & 20.87 & 29.57 & 28.70 & 20.87 & 2.50 & $16^{\text {th }}$ \\
\hline Limited knowledge on adaptive measures & 12.17 & 38.26 & 27.83 & 20.73 & 2.41 & $17^{\text {th }}$ \\
\hline
\end{tabular}

Source: field survey, 2018.

Hint: Variables with 2.5 points and above were considered as serious constraints on adaptation, while below 2.5 were considered as not serious.

consequences of changes brought about by the altering climate are devised.

\section{CONCLUSIONS}

This study examined the factors influencing the choice of climate change adaptation strategies among farming households in Kogi State, Nigeria using the multivariate probit model. The findings from multivariate probit model revealed that the farmers' choice of adaptation strategies are statistically significantly affected by factors such as age, gender, farming experience, credit access, training on climate change, level of education and household size of the household head. The study concluded that rural farmers in the studied area perceived and observed changes in climate and adopted different adaptation strategies to cushion the effects of climate change. It is therefore recommended that relevant stakeholders in the farming industry ensure that decisions which support a wide range of choices of adaptation strategies are made. The study also recommended that consideration should be given to training on climate change, education, credit access, and farm and household size in the formulation of policy on climate change adaptation strategies by policy makers and relevant stakeholders.

\section{SOURCE OF FUNDING}

Self-sponsored. 


\section{REFERENCES}

Adger, W.N., Agrawala, S., Mirza, M.M.Q., Conde, C., O’Brien, K., Pulhin, J. (2007). Assessment of adaptation practices, options, constraints and capacity. In: M.L. Parry, O.F. Canziaw, J.P. Palutikof, P.J. Vander Linden, C.E. Hanson (Eds.), Climate change 2007: Impacts, Adaptation and Vulnerability. Contribution of working group II to the Fourth assessment report of the IPCC (pp. 717-743). Cambridge, UK: Cambridge University Press.

Agrawal, A., Perrin, N. (2009). Climate adaptation, local institutions and rural livelihoods. In: Adger, W.N., Lorenzoni, I., O’Brien, K.L. (Eds.). Adapting to Climate Change: Thresholds, Values, Governance (pp. 350-367). Cambridge: Cambridge University Press.

Amsalu, A., de Graaff, J. (2007). Determinants of adoption and continued use of stone terraces for soil and water conservation in an Ethiopian highland watershed. Ecol. Econ., 61, 294-302.

Bidoli, T.D., Isa, A.G., Shehu, B., Kezi, D.M., Abdullahi, M.Y. (2012). Assessment of the Effects of Climate Change on Livestock Husbandry and Practices in Jigawa State, Nigeria. J. Agric. Ext., 16(1), 20-29.

Chukwuone, N. (2015). Analysis of Impact of Climate Change on Growth and Yield of Yam and Cassava and Adaptation Strategies by Farmers in Southern Nigeria. AGRODEP Working Paper 0012.

Coster, A.S., Adeoti, A.I. (2015). Economic Effects of Climate Change on Maize Production and Farmers' Adaptation Strategies in Nigeria: A Ricardian Approach. J. Agric. Sci., 7(5), 67-84.

Deressa, T.T., Hassan, R.M., Ringler, C., Alemu, T., Yesuf, M. (2008). Analysis of the 'determinants of farmers' choice of adaptation methods and perceptions of climate change in the Nile Basin of Ethiopia. Washington, DC: International Food Policy Research Institute.

Deressa, T.T., Hassan, R.M., Ringler, C. (2011). Perception of and adaptation to climate change by farmers in the Nile basin of Ethiopia. J. Agric. Sci., 149, 23-31.

Egbule, C.L. (2010). Indigenous and emerging adaptive agricultural technologies to climate change in the Niger Delta region of Nigeria. Unpublished MSc Thesis. Nsukka, Enugu State, Nigeria: University of Nigeria.

Fawole, O.P., Olajide, B.R. (2012). Reporting of Climate Change News in Three Nigerian Newspapers. J. Agric. Ext., 16(1), 31-37.

Hassan, R., Nhemachena, C. (2008). Determinants of African farmers' strategies for adapting to climate change: Multinomial choice analysis. Afr. J. Agric. Res. Econ., 2(1), 83-104.
Idrisa, Y.L., Ogunbameru, B.O., Ibrahim, A.A., Bawa, D.B. (2012). Analysis of awareness and adaptation to climate change among farmers in the Sahel Savannah agro-ecological zone of Borno State, Nigeria. Brit. J. Env. Clim. Change, 2(2), 216-226.

IPCC (Intergovernmental Panel on Climate Change). (2015). Climate change: Synthesis report. Contribution of Working Groups I, II and III to the Fifth Assessment Report of the Intergovernmental Panel on Climate Change. Geneva, Switzerland: IPCC.

Kassa, Y., Beyene, F., Haji, J., Legesse, B. (2013). Impact of integrated soil and water conservation program on crop production and income in West Harerghe Zone, Ethiopia. Int. J. Env. Monitor. Anal., 1(4), 111-120.

Keil, A. (2001). Adoption of leguminous tree fallows in Zambia. Discussion Paper No. 33, Göttingen, Germany: Universität Göttingen.

Lin, C.T.J., Jensen, K.L., Yen, S.T. (2005). Awareness of foodborne pathogens among US consumers. Food Qual. Pref., $16,401-412$.

Maddison, D. (2006). The perception of and adaptation to climate change in Africa. CEEPA Discussion Paper No. 10. Centre for Environmental Economics and Policy in Africa. Pretoria, South Africa: University of Pretoria.

Montpellier Panel Report (2015). The farms of change: African smallholders responding to an uncertain climate future. Retrieved from: https://reliefweb.int/sites/reliefweb. int/files/resources/MP_Climate_Report_Web2.pdf

NBS (n. d.). National Bureau of Statistics. Retrieved on Sep $12^{\text {th }} 2009$ from: www.nigerianstat.gov.ng

Nhemachena, C., Hassan, R. (2007). Micro-Level Analysis of Farmers' Adaptation to Climate Change in Southern Africa. IFPRI Discussion Paper No. 00714. Washington DC: International Food Policy Research Institute.

Ogunjumo, A. (2000). Kogi State. In: A.B. Mamman, J.O. Oyebanji, S.W. Petters (Eds.), Nigeria. A People United. A Future Assured (vol. 2). Abuja: Federal Ministry of Information, Gabumo Publishing Co. Ltd.

Okoro, J.C. (2012). Climate change information needs of rural farmers in Enugu state, Nigeria. Unpublished M. Sc Thesis. Nsukka, Enugu State: University of Nigeria.

Sofoluwe, N.A., Tijani, A.A., Baruwa, O.I. (2011). Farmers perception and adaptation to climate change in Osun State, Nigeria. AFJARE 6(20), 4789-4794.

Umunakwe, P.C. (2011). Strategies for climate change adaptation among rural households in Imo state, Nigeria. Unpublished M. Sc Thesis. Nsukka, Enugu State: University of Nigeria.

Wang, J., Mendelsohn, R., Dinarc, R., Huangd, J., Rozellee, S., Zhangd, L. (2009). The impact of climate change on China's agriculture. Agric. Econ., 40, 323-337. 